Review Article

\title{
Review on Role of Home Garden Agroforestry Practices to Improve Livelihood of Small Scale Farmers and Climate Change Adaptation and Mitigation
}

\author{
Sisay Taye Gifawesen ${ }^{1}$, Fikadu Kitaba Tola ${ }^{2}$, Mezgebu Senbeto Duguma ${ }^{2}$ \\ ${ }^{1}$ Department of Agroforestry, Oromia Agricultural Research Institute, Yabello Pastoral and Dry Land Agriculture Research Center, Yabello, \\ Ethiopia \\ ${ }^{2}$ Department of Agroforestry, Oromia Agricultural Research Institute, Bako Agriculture Research Center, Yabello, Ethiopia
}

Email address:

gemsis2018@gmail.com(S. T. Gifawesen), fikadukitaba21@gmail.com(F.K. Tola), mezgebedink2001@gmail.com(M. S. Duguma)

\section{To cite this article:}

Sisay Taye Gifawesen, Fikadu Kitaba Tola, Mezgebu Senbeto Duguma. Review on Role of Home Garden Agroforestry Practices to Improve Livelihood of Small Scale Farmers and Climate Change Adaptation and Mitigation. Journal of Plant Sciences.

Vol. 8, No. 5, 2020, pp. 134-145. doi: 10.11648/j.jps.20200805.15

Received: August 21, 2019; Accepted: December 11, 2019; Published: September 24, 2020

\begin{abstract}
Agroforestry is one of the most conspicuous land use systems across landscapes and agro ecological zones in Africa. Some of the components of Agroforestry systems are; home garden agroforestry, alley cropping, forest farming, wind break, river banks, park land, crop land trees and buffer zones agroforestry practices. Climate change impacts by complex weather-related phenomena have threatened agricultural and forest ecosystems and the livelihood of agricultural and local communities. Agroforestry has an important role in climate change adaptation through diversified land-use practices, sustainable livelihoods, sources of income, enhanced forest and agricultural productivity and reduced weather-related production losses, which enhance resilience against climate impacts. Like few other land use options, agroforestry has real potential to contribute to food security, climate change mitigation and adaptation, while preserving and strengthening the environmental resource base of Africa's rural landscapes. It has a key role to play in landscape-scale mitigation schemes under the REDD+or AFOLU (Agriculture, Forestry and other land uses) concepts. Home garden agroforestry system indicates that adaptation and mitigation to climate change will largely depend on the increased resilience of both agroforestry systems and of local management capacity. Despite less attention has been given to tree based land use option, agroforestry has played a major role in reducing household vulnerability to shocking. Smallholder farmers have already started mainstreaming tree based land use system as resilience to social needs because the poor are more exposed to change; Agroforestry is one of best risk aversion option to make them move out of food insecurity. Generally, agroforestry systems readily bundle both mitigation and adaptation strategies and provide several pathways to securing food security for poor farmers, while contributing to climate change mitigation. Agroforestry should attract more attention in global agendas on climate adaptation and mitigation because of its positive social and environmental impacts.
\end{abstract}

Keywords: Agroforestry System, Home Garden, Climate Adaptation and Mitigation

\section{Introduction}

Agroforestry is one of the most conspicuous land use systems across landscapes and agro ecological zones in Africa [1]. With food shortages and increased threats of climate change, interest in agroforestry is gathering for its potential to address various on-farm adaptation needs, and fulfill many roles in AFOLU (agroforestry and other land uses)-related mitigation pathways. Agroforestry provides assets and income from carbon, wood energy, improved soil fertility and enhancement of local climate conditions; it provides ecosystem services and reduces human impacts on natural forests. Many small holder farmers in Sub-Saharan Africa practice agroforestry. Some of the components of Agroforestry systems are; Home garden agroforestry, Alley 
cropping, Forest farming, Wind break, River banks, Park land, Crop land trees, Buffer zones are some of agroforestry practices. These systems have prevailed despite persistent attempts to introduce monoculture production of annual crops, which have been much less successful in Africa than elsewhere [2]. Agroforestry has been shown to provide a number of benefits to farmers. For instance, it can enhance soil fertility in many situations and improve farm household resilience through provision of additional products for sale or home consumption [3]. The insight that trees on farms provide livelihood benefits is not new, and diversity-based approaches to agricultural adaptation to climate variability have been adopted by many farmers [4].

The world is also concerned with the climate change issues as it is one of the greatest global challenges in the $21 \mathrm{st}$ century that have drawn the attention on many countries [5, 6]. The climate change has become a center of concentration by many governments worldwide due to its induced changes that affect the viability of livelihoods of the poor [7]. This has led to new innovations to respond to the changes and is incorporated in livelihood strategies. More importantly, land use cover changes combined with impact of climate changes have affected the livelihood. Again, land use changes have been identified as the major driving force contributing to environmental change and climate change in particular. Climate change results in changes in ecosystem functions and the ecosystems' capacity to provide society with goods and services, affecting society's options for socio-economic development [8]. Therefore, mitigation and adaptation of the adverse impacts of climate change is a high priority on the international agenda [9].

Climate change adaptation defined as all responses to climate change that can be used to reduce vulnerability [10]. There is a long experience of societies in developing a range of adaptation strategies to the impacts of weather and climate. These include proactive measures like crop and livelihood diversification, irrigation, water management, seasonal climate forecasting, community based disaster risk management and famine early warning systems. They also include reactive or ex-poste adaptations, for example, climate change adaptation through agroforestry. However, adaptation alone is not enough to offset the impacts of climate change, and will thus need to be supplemented by mitigation actions [11]. Adaptation is central to many proposed strategies for reducing the negative impacts of climate change. Adaptive capacity building is increasingly embraced by governments and other institutions as a means to improve economic and ecological resilience. Policymakers draw linkages between a country's financial, human, and institutional capital and its adaptive capacity [12].

Climate changes in the twenty-first century are so large that, even at the low end of the range of possibilities, impacts will require costly adaptations, and in some cases our capacity to adapt will not be enough to avoid serious damage to individuals and society [13]. It will therefore be necessary to reduce climate change by reducing net greenhouse gas emissions to the atmosphere. In the language used by the
Intergovernmental Panel on Climate Change (IPCC) and the United Nations Framework Convention on Climate Change (UNFCCC), this is called 'mitigation'. The big questions are how much emissions should be reduced, how can this be done, and what will it cost? Mitigation, in contrast to adaptation, needs time to take effect due to the lags in the climate system and the time necessary to reduce emissions sufficiently to stabilize climate. Mitigation action taken now will have its most significant effects decades into the future, but is necessary now to limit future climate change [13]. Thus, home garden agroforestry systems are suggested to hold a large potential for climate change mitigation and adaptation. This is due to their multifunctional role in providing income, food and ecosystem services while decreasing pressure on natural forests and hence saving and storing carbon. Hence, the objective of this review paper is to overview the information regarding role of home garden agroforestry practices to improve livelihood of small scale farmers and climate change adaptation and mitigation.

\section{Agroforestry Systems Vs Climate Change}

Agroforestry is a climate-smart production system that sustainably diversifies environmental and socio-economic benefits of subsistence farmers, and is therefore considered more resilient than mono-cropping to increased intensity of extreme weather events [14]. Climate change represents a threat and challenge to Africa because many households, social groups and regions have a limited capacity to adapt to climate variability and change. Eastern and southern Africa's vulnerability to climate change is shaped by the complex interaction of social, political, economic, cultural and environmental factors, all of which are likely to be affected by the projected impacts of climate change [15]. Since not everyone and every place in eastern and southern Africa is equally vulnerable to climate change [15]. Vulnerability to climate change varies greatly among regions, countries, villages, sectors and social groups in eastern and southern Africa.

In recent years, there has been growing interest in agroforestry systems due to their large potential for climate change mitigation and adaptation and their role to mitigate household food security and nutrition from soaring food prices [16-18]. According to report on UN Climate Change Conference 2015 (Paris COP 21), Agriculture directly and indirectly accounts for nearly $25 \%$ of global greenhouse gas emissions and is among the sectors most vulnerable to climate change. With the global population forecast to rise to 9 billion by 2050 , we need to produce enough food to feed and nourish this growing population, and do so with fewer resources and in the face of increasingly erratic weather patterns caused by climate change.

Agriculture is addressed in many Intended Nationally Determined Contributions (INDCs) because of its mitigation potential and possibilities to reduce climate-related risks. 
More sustainable agriculture will also be instrumental in achieving the Sustainable Development Goals (SDGs) that aim to eradicate hunger, reduce poverty, provide affordable and clean energy, and protect life on land and combat climate change. There are ways of making agriculture more sustainable. One of them is agroforestry, a kind of farming that integrates trees into agricultural landscapes thereby increasing food security and nutrition, reducing climate risks and storing carbon to mitigate climate change.

Different categories of Agroforestry have different climate change adaptation or mitigation potential adapted from [19]. Agroforestry and climate change Emmanuel Torquebiau FAO webinar 5 February 2013.

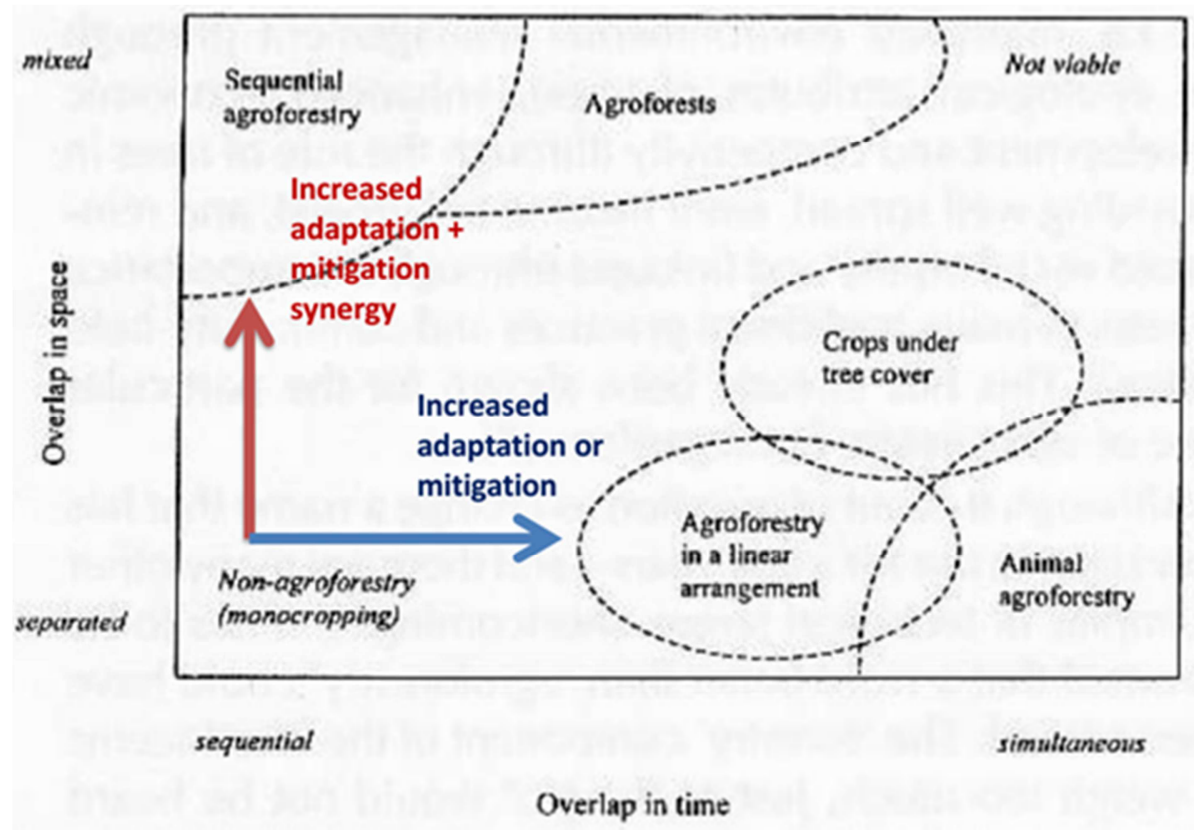

Figure 1. Climate Change Adaptation or Mitigation Potential of Different AF Categories Source: [19].

\subsection{Agroforestry Systems Against Livelihood Improvement and Climate Change}

\subsubsection{Production Diversification}

Agroforestry in general may increase farm profitability through improvement and diversification of output per unit area of tree/crop/livestock, through protection against damaging effects of wind or water flow, and through new products added to the financial diversity and flexibility of the farming enterprise [20]. It can also substantially contribute to climate change mitigation [21-23].

Trees in AFSs can tolerate to drought than crops, therefore it helps to avoid total failure in the farm. A report from [24] pointed out that tree in AFSs are highly valued by farmers because their products compensate for the loss of crop yield. Traditional resource management adaptations, such as agroforestry systems, may potentially provide options for improving farmer adapting to climate change through simultaneous production of food, fodder and firewood as well as mitigation of the impact of climate change [25-26]. Furthermore, there are positive links between agroforestry and adaptation to climate variability, which means agroforestry option may provide a means for diversifying production, increasing resilience of subsistence farmers and buffering against production risk associated with climate [27, 21].

A central hypothesis in agro forestry is that productivity is higher in agroforestry systems compared to monoculture systems due to complementarities in resource-capture i.e. Trees acquire resources that the crops alone would not. This is based on the ecological theory of niche differentiation; different species obtain resources from different parts of the environment, such as, tree roots of Persea americana and Syzigium species extend deeper than crop roots and are therefore able to access soil nutrients and water unavailable to crops, as well as absorb nutrients leached from the crop rhizosphere [28-29]. In drought-prone environments, such as Rajasthan, as a risk aversion and coping strategy against climate variability, farmers maintain agroforestry systems to avoid long-term vulnerability by keeping trees as an insurance against drought and insect pest outbreaks [30].

The study conducted in Mwanga district of Tanzania indicated that the diversification of crops in agroforestry systems was among the coping strategy used by farmers to support them during drought, these involved intercropping more than three crops on the same piece of land, such crops included maize, paddy, cassava, sweet potato, sun flower, beans, horticultural crops, coffee, pineapple, yams, taro, nuts, sugarcane, passion crops and cardamom [14].

\subsubsection{Carbon Sequestration}

AFPs provide an opportunity of responding to the adverse impacts of climate change through the joint action of adaptation and mitigation [21, 31]. In mitigating climate changes crops and trees on farm can be a major source of carbon sinks. The double potential of AF to address climate 
change issues includes:-Greenhouse gas-mitigation strategy through carbon sequestration because of greater efficiency of integrated systems in resource (nutrients, light, and water) capture and utilization than single-species systems [32]. Sustainable adjustment to changing conditions because AFSs can be called perennial farming systems. They maintain and develop their root and woody biomass throughout seasons while providing food, fiber, energy and vegetative cover for soils. AF has a high carbon sequestration potential on the long term (e.g. by the year 2040) not because it has a high carbon density (compared to forests) but because a lot of lands can potentially be turned into AF.

UNFCCC defines carbon sequestration as the process of removing $\mathrm{C}$ from the atmosphere and depositing it in a reservoir. It entails the transfer of atmospheric $\mathrm{CO}_{2}$, and its secure storage in long-lived pools. From the AF point of view, $\mathrm{C}$ sequestration primarily involves the uptake of atmospheric $\mathrm{CO}_{2}$ during photosynthesis and the transfer of fixed $\mathrm{C}$ into vegetation, detritus, and soil pools for "secure" (i.e. long-term) storage [33]. It occurs in two major segments of the AFS: above ground and below ground. Each can be partitioned into sub-segments: the former into specific plant parts (stem, leaves, etc., of trees and herbaceous components), and the latter into living biomass such as roots and other below ground plant parts, soil organisms, and $\mathrm{C}$ stored in various soil horizons. The total amount sequestered in each compartment differs greatly depending on a number of factors including the eco-region, the type of system (and the nature of components and age of perennials such as trees), site quality, and previous land use. On average, the above ground parts and the soil (including roots and other living biomass) are estimated to hold roughly one-thirds and two-thirds, respectively, of the total $\mathrm{C}$ stored in tree-based land use systems [34]. Based on the notion that tree incorporation in croplands and pastures would result in greater net $\mathrm{C}$ storage above-and below ground [35, 36]. AFS are believed to have a higher potential to sequester $\mathrm{C}$ than pastures or field crops growing under similar ecological conditions [37-38].

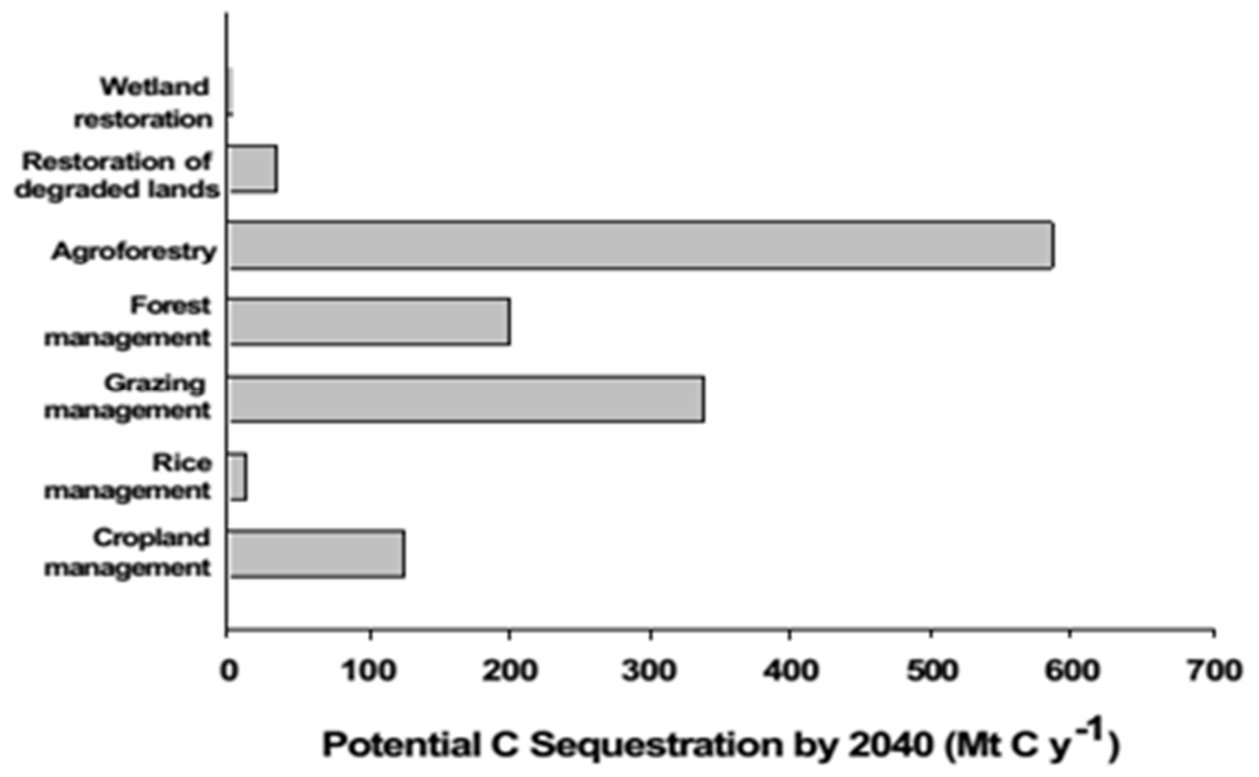

Figure 2. Carbon sequestration potential of different land use and management options adapted from [21].

AF has a dual role to play in the climate change area. AF has a particular role to play in mitigation of atmospheric accumulation of GHGs according the IPCC. Of all the land uses analyzed in the Land-Use, Land-Use Change and Forestry report of the IPCC, AF offered the highest potential for carbon sequestration in developing countries (Figure 1). Agroforestry is just one of a number of improved farming practices can increase the sustainability of farming systems and contribute to reducing farmers' vulnerability to climate variability while sequestering carbon from the atmosphere. Trees store carbon in their trunks, leaves and roots. This carbon capture contributes to reducing the level of emissions particularly of carbon dioxide and methane from farming. Expert's estimate that a quarter of all global greenhouse gas emissions come from agriculture.

\subsubsection{Income Generation}

Trees on farms plays important role to enhance the coping capacity of smallholder farmers to climate change risks through crop and income diversification, soil and water conservation and efficient nutrient cycling [39]. If supported by appropriate cultivation, processing and marketing methods, AF products can make a major contribution to the economic development of the millions of poor farmers by meeting their needs for food, fuel and income. Combined yields of tree, crop and livestock products from well planned and well managed AFSs tend to be higher than those from sole systems due to increased and efficient use of scarce resources especially moisture.

\subsubsection{Ecosystem Protection}

As an adaptation option sustainable AFPs can be potential 
for protecting ecosystems and livelihood, and creating foundation for economic and social development [40]. Furthermore, AFPs provide ecosystem services, and are a means of diversifying agricultural production and increase food security for farmers, especially under current climate change scenarios [21, 24].

Our changing climate and burgeoning population urgently needs agricultural techniques that can produce more on less land and with fewer inputs, while keeping the environment healthy. As such, sustainable agriculture that brings climate adaptation and mitigation benefits is one of the issues to be tackled at the 21 st UN climate conference (COP 21), in Paris, $\quad 30 \quad$ November, 2015. (See www.worldagroforestry.org/cop21 for the full program of ICRAF's activities at Paris COP21).

Agro-ecological practices such as AF, which involves integrating the right trees and woody shrubs into agricultural landscapes are an important part of the solution. The trees to use for AF can be selected so they deliver products and services that improve not only farmers' lives and countries' economies, but also the environment. The right trees in the right place have been shown to build farmers' resilience to climate related shocks such as unpredictable and extreme weather; they do this both by diversifying income sources, and by providing environmental services such as soil improvement, flood control and wind shelter. This is in addition to producing fresh air and bringing beauty and biodiversity to living spaces, which promotes human health and well-being. Sustainable, environmentally friendly food and fuel production is possible with agroforestry and by bringing the products and services people need from trees close to human habitats, agroforestry can reduce harvesting pressure on forests.

Although carbon sequestration through afforestation and reforestation of degraded natural forests has long been considered useful in climate change mitigation, AF offers some distinct advantages. The planting of trees along with crops improves soil fertility, controls and prevents soil erosion, controls water logging, checks acidification and eutrophication of streams and rivers, increases local biodiversity, decreases pressure on natural forests for fuel and provides fodder for livestock [41]. It also has the ability to enhance the resilience of the system for coping with the adverse impacts of climate change.

\subsubsection{Soil and Water Conservation}

The most worrisome component of climate change from the point of view of smallholder farmers is increased inter annual variability in rainfall and temperature. Tree based systems have some obvious advantages for maintaining production during wetter and drier years. First, their deep root systems are able to explore a larger soil volume for water and nutrients, which will help during droughts. Second, increased soil porosity, reduced runoff and increased soil cover lead to increased water infiltration and retention in the soil profile which can reduce moisture stress during low rainfall years. Third, tree-based systems have higher evapotranspiration rates than row crops or pastures and can thus maintain aerated soil conditions by pumping excess water out of the soil profile more rapidly than other production systems [42]. Noteworthy among such practices in tropical environments include incorporation of fastgrowing, nitrogen fixing trees and shrubs in agricultural fields to improve soil fertility and minimize erosion, improved management of fallows, domestication of new and underutilized tree species, and intensification of agriculture on smallholder farms through use of appropriate tree and shrub species. A wide range of AFSs now exist with a potential to improve productivity, favorably influence microclimate, prevent soil degradation and restore soil fertility and diversify income generating opportunities [43].

\subsubsection{Addressing Food Security}

Most of the food consumed in Eastern Africa is produced by smallholder farmers. However, their productivity has been falling, frequently as a result of declining soil fertility. In parts of Ethiopia, water scarcity, uncontrolled grazing and the high demand for tree products is leading to severe environmental degradation and declining yields. Many smallholder farmers in Sub-Saharan Africa practice agroforestry. These systems have prevailed despite persistent attempts to introduce monoculture production of annual crops, which have been much less successful in Africa than elsewhere. Agroforestry has been shown to provide a number of benefits to farmers. For instance, it can enhance soil fertility in many situations and improve farm household resilience through provision of additional products for sale or home consumption [3].

The insight that trees on farms provide livelihood benefits is not new, and diversity-based approaches to agricultural adaptation to climate variability have been adopted by many farmers. In light of recurring food shortages, projected climate change, and rising prices of fossil fuel-based agricultural inputs, agroforestry has recently experienced a surge in interest from the research and development communities, as a cost-effective means to enhance food security, while at the same time contributing to climate change adaptation and mitigation. It has also experienced a recent increase in adoption by farmers in many parts of Africa as demonstrated by [44].

Agroforestry technologies are ensuring food security and are lifting many out of poverty and mitigating declining agricultural productivity and natural resources. Remarkable examples are: fertilizer trees that when integrated with inorganic fertilizers can double or triple crops yields in degraded lands, fodder trees that can be used in smallholder zero-grazing systems in ways that supplement or substitute commercial feeds, improved varieties of temperate and tropical fruits that can be used to supplement household incomes and nutrition, medicinal trees that are utilized on farm and conserved in-situ, and fast-growing timber and fuel wood trees that can be grown in various niches within the farm and in commercial woodlots and plantations [45]. According to [46] agroforestry can contribute to food 
security through the provision of edible products such as fruits, roots and seeds, and can also improve soil fertility by fixing nitrogen from the air and recycling nutrients, thereby helping to increase crop yields. The framework under which agroforestry could contribute to food security, social wealth and climate change alleviation requires a clear understanding of the components and processes that are relevant for sustainable management of benefit flows from ecosystem services in changing agricultural landscapes.

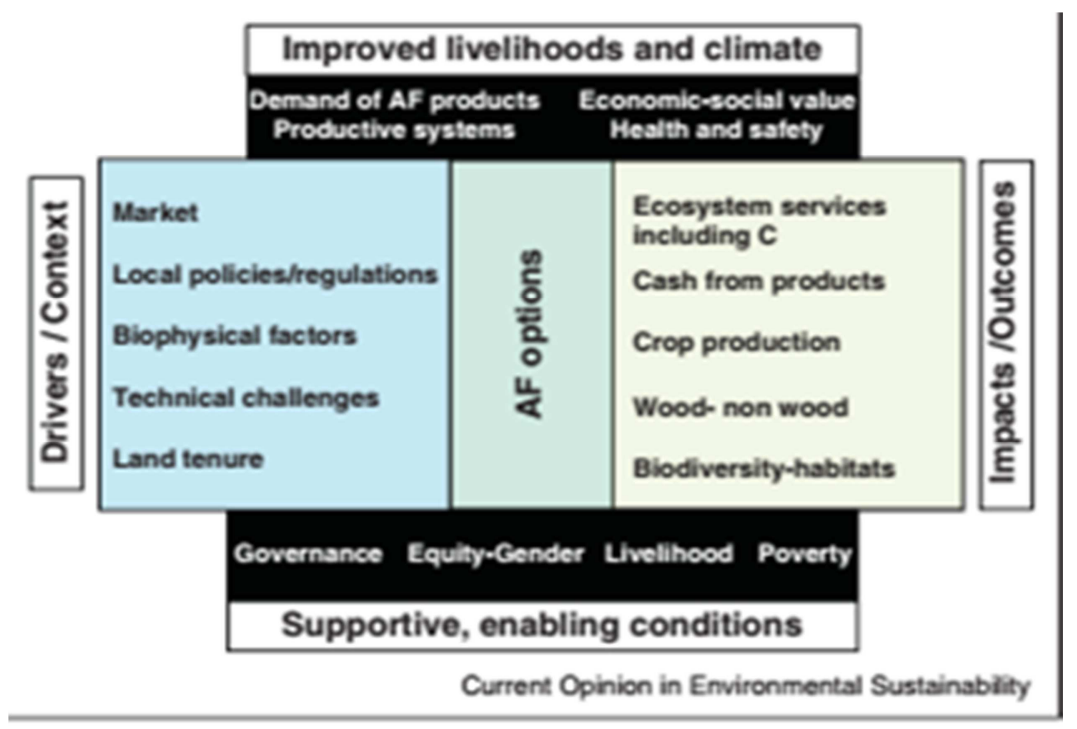

Source: Current Opinion in Environmental Sustainability 2014, www.sciencedirect.com.

Figure 3. Suggests factors that significantly impact on the success of AF.

\subsection{Climate Change Vs Livelihood}

The climate change has become a center of concentration by many governments worldwide due to its induced changes that affect the viability of livelihoods of the poor [7]. This has led to new innovations to respond to the changes and is incorporated in livelihood strategies. More importantly, land use cover changes combined with impact of climate changes have affected the livelihood. Again, land use changes have been identified as the major driving force contributing to environmental change and climate change in particular [47]. Climate change results in changes in ecosystem functions and the ecosystems' capacity to provide society with goods and services, affecting society's options for socio-economic development [8]. Climate is a critical factor affecting forest ecosystems and it has the capacity to cause the ecosystems to change to new status, for example, it can change from forest to savannah [8].

Therefore, mitigation and adaptation of the adverse impacts of climate change is a high priority on the international agenda [9]. However, the main challenges remain in developing best practices for adaptive measures to maintain ecosystem resilience and to reduce vulnerability in the presence of various climate change scenarios [48]. Despite the fact that climate change impacts are on global scale, African countries are the most vulnerable to the impacts of climate change and variability due to high level of poverty, low resilience and weak institutional capacity [49]. As a result, these impacts of climate change and variability have undermined the efforts made in improving the socioeconomic development of African countries. This indicates that efforts are needed to prepare the developing countries to respond to the climate related impacts [50]. Climate is the major factor that influence agriculture practices and according to [24]; climate change has already affected the agriculture sector. It is a human activity that is most vulnerable to the impact of climate change [51].

\section{The Concern of Home Garden Agroforestry System}

In this Review, our discussion has focused more on the home garden agroforestry practice because of the following reasons;

\subsection{It Has Large Potential for Climate Change Adaptation and Mitigation to Improve Livelihood of Small Scale Farmers}

Home garden agroforestry systems are suggested to hold a large potential for climate change mitigation and adaptation. This is due to their multifunctional role in providing income, food and ecosystem services while decreasing pressure on natural forests and hence saving and storing carbon [52]. Home gardens are agroforestry systems common throughout the tropics [53, 54]. Home gardens are prime examples of multi-functional landscapes: spaces that combine agriculture, forestry and natural ecosystems and are in Sri Lanka defined as a complex sustainable land-use system that combines multiple farming components, such as annual and perennial crops, livestock and occasionally fish, of the homestead and provides environmental services, household needs, and 
employment and income generation opportunities to the households [55]. Others, such as, [56, 53] provide a similar definition and suggest that a home garden includes the concept of intimate plant associations of various trees and crops, sometimes in association with domestic animals, and consequent multi-story canopy configuration around the homestead.

\subsection{It Has More Diversity of Species and Multi-functional}

Tropical home gardens consist of an assemblage of multipurpose trees and shrubs with annual and perennial crops and livestock within compounds of individual houses managed by family labor. The home gardens are characterized by high species diversity and usually 3-4 vertical canopy strata - tree layers' upper story, herbaceous layer near the ground and intermediate layers in between. The ensete-coffee-livestock tree system of southwestern Ethiopia represents a typical multistory home garden. The upper story is dominated by broadleaved trees (e.g., Cordia, Croton, Millettia) fruit crops (avocado, mango), the middle story containing ensete, coffee and maize while vegetables, spices, herbs cover the lower canopies. This results in a continuous food production throughout the year [45]. Despite the lack of a uniform definition of home gardens they are second to shifting cultivation the oldest land-use systems worldwide that have evolved through centuries of biological and cultural transformation [53, 57]. Home gardens also store higher amounts of carbon than other agriculture systems in the above-and below-ground biomass and soils, but usually inferior to mature forests at the same site [58, 52]. The provisioning role of agroforestry and home gardens to maintain species diversity may also facilitate more stable and longer term stability of carbon stocks as well as diversification of home garden derived products [59, 60, 61].

A number of adaptation case studies emphasize the importance of diverse home gardens in ensuring the family food supply in areas significantly affected by climate change. Examples from Bangladesh describe two types of adaptation strategies for enhancing the resilience of home gardens. In drought-prone regions, the resilience of traditional homestead gardens is strengthened through intercropping of fruit trees with vegetables, small-scale irrigation and organic fertilizers [62]. In the flood-affected regions, floating gardens have been created for cultivation of a mix of traditional crops, including saline-tolerant vegetables such as bitter gourd, red amaranth and kohlrabi. The floating gardens, in combination with alternative farming methods such as duck rearing and fishing, are important source of food during floods [63].

In many parts of the world home garden systems provide supplementary food, fuel, fodder and serve as a recovery area for the people. Home gardens in the tropics vary greatly in species, species richness, structural complexity and size. Most of them display different vegetation layers making them typical agroforestry systems [64].

Generally, home garden agroforestry is believed to be more diverse and provide multiple services for household than other mono-cropping system and this is due to the combination of crops, trees and livestock, home garden agroforestry practice provides good socio-economical and agro-ecological service for farmers which have a higher implication for climate change adaptation than non-tree based garden [65]. Despite its vast socio-economic importance, in Ethiopia the agro-ecosystem and socioeconomic role of home garden AF are very few.
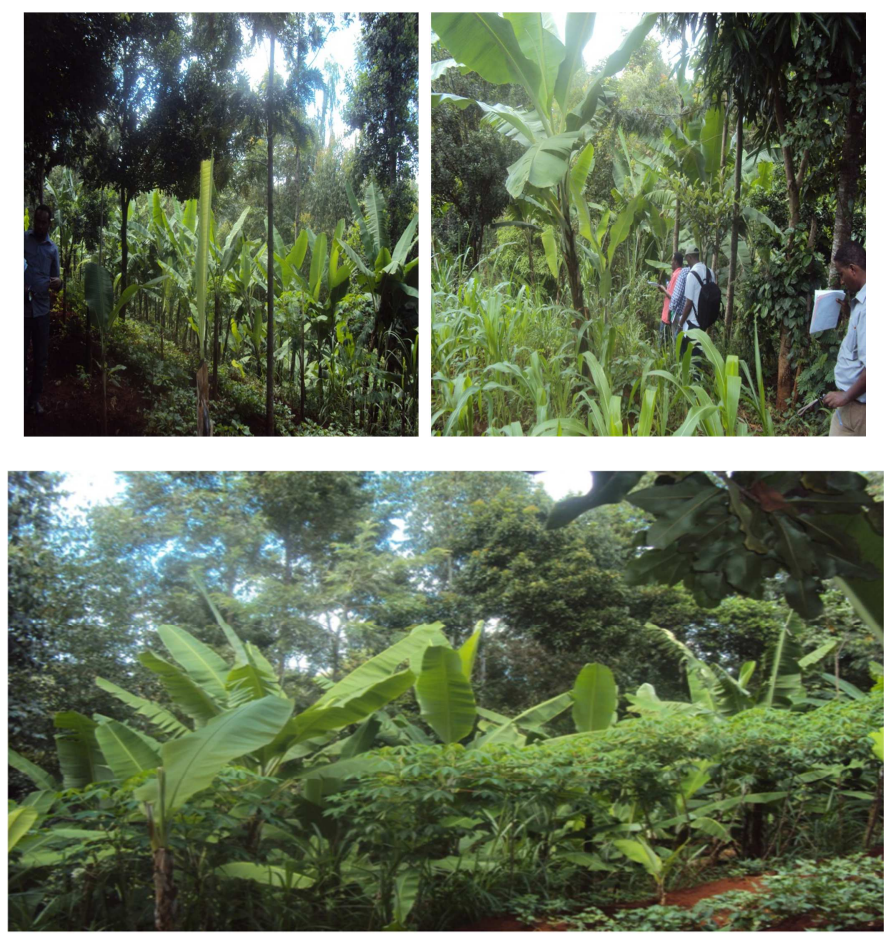

Source: Picture by second author Mezgebu Senbeto, May 20, 2013 during field visit of western Kenya

Figure 4. Species diversity of home garden agroforestry, Embu, Kenya. 


\subsection{Easily Manageable}

In general, home gardens are characterized by different vegetation strata composed of trees, shrubs and herbs in association with annual and perennial agricultural crops and small livestock within the house compounds in which normally the whole tree-crop-animal unit is intensively managed by family labor [66]. In Bangladesh, there is no specific management plan for the homestead forests which are being traditionally managed by the household owners [31].

\subsection{Year Round Productivity and Social Value}

Home gardens are known to serve a number of functions to the household. They allow an almost year-round production of food due to the diverse crops maintained; are sources of products such as medicinal plants, construction materials, fuel, and beauty aids; are important in generating income to the household; make use of the local labor thereby making people engaged; have a role in strengthening the social bonds among community members; serve as a symbol of status; and are also valuable sites for agro biodiversity conservation [67].

\section{Gaps and Challenges of Agroforestry Systems in Climate Adaptation and Mitigation}

Communities in the past have shown resilience and capacity to adapt to changes in climate through keen observation, experimentation and practice, adaptation to the rapid changes that are taking place in global climate and other sectors are beyond that of a natural self-correcting process. They require carefully planned interventions including supportive policies and regulations to mitigate the impacts of expected changes in climate while meeting household level requirements for food, fuel and income.

There are, however, a number of technical challenges to the introduction and expansion of agroforestry [68]. Many are associated with misperceptions concerning the interactions between trees and crops, and most can be solved through demonstration and training. Many of the obstacles to wider use of agroforestry are related to policies. Agricultural policies often entirely ignore trees on farms, so agricultural authorities do not develop incentives for tree cultivation or include agroforestry in extension and other guidance. For example, until recently farmers in the European Union were not eligible for Common Agricultural Policy subsidies for cereals if they grew their grains in association with trees, and more recent policy that is favorable to agroforestry has been weakly implemented to date. And in the USA, agroforestry has not been well recognized, although a June 2011 announcement of an Agroforestry Plan by the U.S. Department of Agriculture expects to strategically use programs such as farm and conservation assistance, forest landowner assistance, extension, education and outreach, and many other services to promote agroforestry.

Another major challenge, in particular for resource - poor farmers in developing countries is that trees are perennial crops that are comparatively slow to grow. This means that farmers need to invest scarce resources in tree establishment and management, and do not begin to see benefits for a number of years. Policies are needed to provide incentives for investment in advance of benefit. Thus, there is little incentive as yet for farmers to generate the many societal environmental services that are possible through agroforestry. Trees on farms are often governed by over-reaching forestry legislation that treats all trees as though they are in forests, and punishes farmers for managing trees on their land.

\section{Conclusion and Recommendations}

\subsection{Conclusion}

Climate change impacts by complex weather-related phenomena have threatened agricultural and forest ecosystems and the livelihood of agricultural and local communities. Agroforestry has an important role in climate change adaptation through diversified land-use practices, sustainable livelihoods, sources of income, enhanced forest and agricultural productivity, and reduced weather-related production losses, which enhance resilience against climate impacts. Like few other land use options, agroforestry has real potential to contribute to food security, climate change mitigation and adaptation, while preserving and strengthening the environmental resource base of Africa's rural landscapes. It has a key role to play in landscape-scale mitigation schemes under the REDD+or AFOLU (Agriculture, Forestry and other land uses) concepts. For millions of African farmers whose livelihoods are threatened by climate change and land degradation agroforestry offers a pathway toward more resilient livelihoods. Sustainable agroforestry management, along with raising awareness, strengthening technical capacities, creating policies for actions that encourage cross-sectorial and landscape approaches, is a key to helping agriculture-and forestdependent people adapt to new conditions caused by climate change. However, not all agroforestry options are viable everywhere, and the current state of knowledge offers very little guidance on what systems work where, for whom and under what circumstances.

Home garden agroforestry system (AFS) indicates that adaptation and mitigation to climate change will largely depend on the increased resilience of both AFSs and of local management capacity. Local biophysical conditions and socioeconomic factors must also be assessed and considered along with AFPs in order to effectively reduce the vulnerability of these communities to climate change. The great potential of tree component of AFS in increasing C sequestration compare with treeless agricultural systems, and 
therefore its implementation should be considered as a climate smart land use option. Despite less attention has been given to tree based land use option, AF has played a major role in reducing household vulnerability to shocking. Smallholder farmers have already started mainstreaming tree based land use system as resilience to social needs because the poor are more exposed to change; $\mathrm{AF}$ is one of best risk aversion option to make them move out of food insecurity.

Generally, agroforestry systems readily bundle both mitigation and adaptation strategies and provide several pathways to securing food security for poor farmers, while contributing to climate change mitigation. Agroforestry should attract more attention in global agendas on climate adaptation and mitigation because of its positive social and environmental impacts.

\subsection{Recommendations}

Agroforestry, like any single coping strategy, will not prove to be the silver bullet to climate change adaptation, mitigation and food security. However, agroforestry practices do have substantial potential to help smallholder farmers and pastoralists improve their well - being and the environmental sustainability of their farms and landscapes. By adopting the recommendations outlined below, we believe that agroforestry can be a cornerstone of climate-smart agriculture and contribute, as a part of larger development initiatives, to helping those who depend upon on agriculture for their livelihoods to better adapt to future climate change:

I. The possible gains in $\mathrm{C}$ stocks that could be used to promote $\mathrm{AF}$ as a promising $\mathrm{CO}_{2}$ mitigations strategy

II. Provide an enabling legal and political environment with an overarching national plan, appropriate institutions and effective and transparent governance structures that coordinate between sectorial responsibilities and across national to local institutions.

III. Improve market accessibility and development of markets for ecosystem services to enhance income generating opportunities provided by agroforestry. This can be done through improving infrastructure or more locally through establishing cooperatives that pool resources to access markets.

IV. Involve farmers and pastoralists in the project planning process. Those who depend upon agriculture for their livelihoods should be empowered to ensure that development efforts target what is most relevant to local communities and contexts to accomplish agreed goals in the most effective way.

V. Improve access to knowledge and germplasm. This has been shown to significantly improve farmers' willingness to plant or cultivate more trees for multiple purposes. Farmer to farmer dissemination and educational visits provide potential alternative mechanisms and increase adoption rates.

VI. Improve land and tree tenure. This can have a significant effect on farmers' willingness to invest in their land and improve productivity. Reducing state regulation of farmer management, harvesting and selling of trees on their own farms is an important reform needed in many countries.

VII. Overcome the barriers of high opportunity costs to land. This is a key requirement for successful implementation of climate - smart agriculture in developing countries and to - date it has been given little attention. Many improved management practices provide benefits to farmers only after considerable periods of time. This can be prohibitive for poor households because investing in new practices requires labor and incurs costs that must be borne before the benefits can be reaped. Payments for carbon sequestration may be an appropriate way of covering the time lag between investing in climate smart practices and obtaining the environmental and economic benefits.

VIII.Improve access to farm implements and capital. Credits, loans and other forms of access to capital can significantly reduce farmer vulnerability, particularly in combination with insurance schemes that protect against income losses arising from weather extremes.

\section{References}

[1] Cheikh M, Pete S, David S, Lalisa D and, Mercedes B 2013: Achieving mitigation and adaptation to climate change through sustainable agroforestry practices in Africa. Published by Elsevier Ltd.

[2] Djurfeldt G, Hiolmen H, Jirstrom M, Larsson R: The African Food Crisis. CABI Publishing; 2005.

[3] Thangataa PH, Hilderbrand PE, 2012. Carbon stock and sequestration potential of agroforestry systems in smallholder agroecosystems of sub-Saharan Africa: mechanisms for 'reducing emissions from deforestation and forest degradation '(REDD+). Agric Ecosyst Environ 2012, 158: 172-183.

[4] Nguyen Q, Hoang MH, O" born I, Noordwijk MV: Multipurpose agroforestry as a climate change resiliency option for farmers: an example of local adaptation in Vietnam. Climatic Change 2013, 117: 241-257.

[5] IPCC (2007). Summary for policy makers. In: Parry, M. L., Canziani, O. F., Palutikof, J. P., van der Linden, P. J and Hanson, C. E. (eds). Climate Change: Impacts, Adaptation and Vulnerability. Contribution of Working Group II to the Fourth Assessment Report of the Intergovernmental Panel on Climate Change. Cambridge University Press, Cambridge, UK, 7-22.

[6] UNFPA (2009). State of world population report. Facing world: Women, Population and Climate. World watch Institute. $94 \mathrm{pp}$.

[7] Carney D, 1998. Sustainable rural livelihood: Changing climate, philosophical Transactions of Royal Society, DFID London.

[8] IUFRO (2009). Adaptation of forests and people to climate change, A Global Assessment Report, Seppala, R., Buck, A., and Katila, P. (eds.) International Union of Forest Research Organizations (IUFRO) World Series Volume 22. Helsinki. $224 \mathrm{pp}$. 
[9] IFPRI (2008). Global carbon market: are there opportunities for Sub-Saran Africa? International Food Policy Research Institute (IFPRI) discussion paper 00832.

[10] UNEP (2001). Vulnerability indices. Climate change impacts and adaptation. United Nations Environment Programme (UNEP) Policy Series. UNEP. 91 pp.

[11] ECA. (2009). Shaping climate-resilient development: A framework for decision-making. A report of the Economics of Climate Adaptation (ECA) working group, Climate Works Foundation, Global Environment Facility, European Commission, McKinsey and Company, The Rockefeller Foundation, Standard Chartered Bank and Swiss Re.

[12] Roberts GJ, Parrotta, and Wreford A., 2009. Current adaptation measures and policies, pp. 123-134 in Adaptation of Forests and People to Climate Change. R. Seppälä, A. Buck, and P. Katila, eds. Helsinki, Finland.

[13] Pittock A. B, 2009, Climate Change; The Science, Impacts and Solutions, Second edition, USA.

[14] Richard L. Charles, P. K. T. Munishi and Emmanuel. F. Nzunda, 2013, Agroforestry as Adaptation Strategy under Climate Change in Mwanga District, Kilimanjaro, Tanzania, International Journal of Environmental protection Vol. 3 Iss. 11, PP. 29-38.

[15] Eriksen, T. R. J. Klein, K. Ulsrud, O. L. Nass and K. O’Brien, "Climate change adaptation and poverty reduction: Key interactions and critical measures," Report prepared for the Norwegian Agency for Development Cooperation (NORAD). Oslo: University of Oslo, p. 44, 2008.

[16] Minang PA, van Noordwijk M, Swallow BM (2012) Highcarbon-stock rural development pathways in Asia and Africa: improved land management for climate change mitigation. In: Nair PKR, Garrity DP (eds) Agroforestry: the future of global land use. Springer, the Netherlands, pp 127-143.

[17] Nair PKR (2012) Climate change mitigation: a low-hanging fruit of agroforestry. In: Nair PKR, Garrity D (eds) Agroforestry - the future of global land use. Springer, Dordrecht, pp 31-67.

[18] Galhena DH, Freed R, Maredia KM (2013) Home gardens: a promising approach to enhance household food security and wellbeing. Agric Food Secur 2 (8): 48-62.

[19] Torquebiau E, 2013. Agroforestry and climate change. FAO webinar 5 February 2013.

[20] Molua EL: The economics of tropical agroforestry systems: the case of agroforestry farms in Cameroon. Forest Policy Econ 2005, 7: 199-211.

[21] Verchot LV, A. Albiecht, S. Kandji, M. V. Noordwijk, T. Tomich, C. Ong, J. Mackensen, C. Bantilan, K. V. Anupama and C. Palm, 2007. "Climate change linking adaptation and mitigation through agroforestry", Mitig Adapt Strat Global change. vol. 12, pp. 901-918.

[22] Smith P, Wollenberg E: Achieving mitigation through synergies with adaptation. In Climate Change Mitigation and Agriculture. Edited by Wollenberg E, Nihart A, TapioBostro"m M-L, Grieg-Gran M. London-New York: ICRAFCIAT; 2012: 50-57.

[23] Pandey DN: Carbon sequestration in agroforestry systems. Climate Policy 2002, 2: 367-377.
[24] Ekpo FE and Asuquo, M. E, 2012. Agroforestry practice as adaptation tools to climate change hazards in Itu Lga, Akwa Ibom State, Nigeria. Global Journal of Human Social Science Geography \& Environmental Geosciences. 12 (11): 27-36.

[25] Adger ND. Moran, and A. Wreford, "Climate change and Agriculture: impacts, adaptation and mitigation," Organization for Economic Co-operation and Development (OECD), p. $140,2010$.

[26] Nair PKR, B. M. Kumar and V. D. Nair, "Agroforestry as a strategy for carbon sequestration," Journal of Plant Nutrition. Soil science, vol. 172, pp. 10-23, May. 2008.

[27] Adger WN, Arnel NW and Tompking EL, "Successful adaptation to climate change across scales," Global Environmental change. Vol. 15, pp. 77-86, Dec. 2004.

[28] Smith J, (2010) Agro forestry: Reconciling production with protection of the environment. A synopsis of Research literature. Organic Research Centre. Elm Farm, p. 24, 2010.

[29] Pandey DN, "Multifunctional agroforestry systems in India; CIFOR, Bogor, Indonesia," Current science. vol. 92, pp. 455463, Feb. 2007.

[30] Singh S. V., and Pandey D. N., Multifunctional Agroforestry Systems in India: Science-Based Policy options. Climate change and CDM Cell Rajasthan State Pollution Controll Board, p. 35, 2011.

[31] Roy B, Habibur R, and Jannatul F, 2013; Status, Diversity, and Traditional Uses of Homestead Gardens in Northern Bangladesh: A Means of Sustainable Biodiversity Conservation, Bangladesh.

[32] Nair PKR. et al., 2009. Agroforestry as a strategy for carbon sequestration. J. Plant Nutr. Soil Sci. 172: 10-23.

[33] Nair PKR, Nair VD, Kumar BM, Showalter JM, 2010. Carbon sequestration in agroforestry systems. Adv Agron 108: 237307.

[34] Lal R, 2010. Managing soils and ecosystems for mitigating anthropogenic carbon emissions and advancing global food security. Bioscience 60: 708-721.

[35] Palm C, Tomich T, Van Noordwijk M, Vosti S, Alegre J, Gockowski J, Verchot L, 2004. Mitigating GHG emissions in the humid tropics: case studies from the Alternatives to Slashand-Burn Program (ASB). Environ Dev Sust 6: 145-162.

[36] Haile SG, Nair PKR, Nair VD, 2008. Carbon storage of different soil-size fractionsin Florida silvopastoral systems. J Environ Qual 37: 1789-1797.

[37] Roshetko JM, Delaney M, Hairiah K, Purnomosidhi P (2002) Carbon stocks in Indonesian homegarden systems: can smallholder systems be targeted for increased carbon storage? Am J Altern Agric 17: 138-148?

[38] Kirby KR, Potvin C, 2007. Variation in carbon storage among tree species: implications for the management of a small-scale carbon sink project. For Ecol Manag 246: 208-221.

[39] Lasco R, and Pulhin, F, 2009. Agroforestry for climate change adaptation and mitigation. An academic presentation for the College of Forestry and Natural Resources (CFNR), University of the Philippines Los Banos (UPLB), Los Banos, Laguna, Philippines. 
[40] Mangala PZ and Makoto, I, 2014. Climate change and agroforestry management in Sri Lanka: Adverse impacts, adaptation strategies and policy implications. Department of Agricultural Economics, University of Ruhuna, Matara, Sri Lanka and Department of Global Agricultural Sciences, The University of Tokyo, Tokyo, Japan.

[41] Makundi WR, Sathaye JA, 2004. GHG mitigation potential and cost in tropical forestry-relative role for agroforestry. Environment, Development and Sustainability 6: 235-260.

[42] Regional Report, 2005. Climate Change and Development in East Africa: African Centre for Technology Studies (ACTS) Nairobi, Kenya.

[43] Rao KPC, Louis V Verchot and Jan Laarman, 2007. Adaptation to Climate Change through Sustainable Management and Development of Agroforestry Systems. World Agroforestry Center, an Open Access Journal published by ICRISAT, SAT eJournal | ejournal.icrisat.org December 2007 | Volume 4 | Issue 1.

[44] Garrity DP, Akinnifesi FK, Ajayi OC, Weldesemayat SG, Mowo JG, Kalinganire A, Larwanou M, Bayala J, 2010. Evergreen agriculture: a robust approach to sustainable food security in Africa. Food security 2: 197-214.

[45] Getachew M, "Evergreen Agriculture: Agroforestry for Food Security and Climate Change Resilience", Journal of Natural Sciences Research, ISSN 2224-3186 (Paper) ISSN 2225-0921 (Online); Vol. 4, No. 11, 2014.

[46] Bishaw B, Henry N, Jeremias M, Abdu A, Jonathan M, Gemedo D, Tewodros A, Kathleen G, Habtemariam K, Ian KD, Eike L, and Cheikh M. 2013. Farmers' Strategies for Adapting to and Mitigating Climate Variability and Change through Agroforestry in Ethiopia and Kenya, edited by Caryn M. Davis, Bryan Bernart, and Aleksandra Dmitriev. Forestry Communications Group, Oregon State University, Corvallis, Oregon.

[47] IIASA (International Institute for Applied System Analysis, 1998). Three scenarios for land use change: A case study in Central Europe. International Standard Book, Number 3-70450132-8.

[48] IUFRO, FAO, SLU, 2008. International conference on adaptation of forests and forest management to changing climate with emphasis on forest health: A review of science, policies and practices: Book of abstracts and preliminary programme. Swedish University of Agricultural Sciences (SLU) Food and Agriculture Organization of the United Nations (FAO) and International Union of Forest Research Organizations (IUFRO), Umea, Sweden.

[49] IPCC (Intergovernmental Panel on Climate Change), 2001 a. Climate Change 2001. Synthesis report, Cambridge University Press, Cambridge, UK. Druckhans Grasl. Bad Vosku. Austria.

[50] FAO, 2007. Adaptation to climate change in agriculture, forestry and fisheries: Perspective, framework and priorities. Interdepartmental Working Group on Climate Change, Food and Agriculture Organization (FAO) of the United Nations, Rome.

[51] Roy, M. M., Tewari, J. C. and Ram, M, 2011. Agroforestry for climate change adaptation and livelihood improvements in India hot arid region. International Journal of Agriculture and Crop Sciences (IJACS). 3 (2), 43-54.

[52] Mattsson E, Ostwald M, Nissanka SP, Marambe B (2013)
Home gardens as a multi-functional land use strategy in Sri Lanka with focus on carbon sequestration. Ambio 42: 892902.

[53] Nair PKR, Kumar BM (2006) Introduction. In: Kumar BM, Nair PKR (eds) Tropical home gardens: a time-tested example of sustainable agroforestry. Springer, Dordrecht, pp 1-10.

[54] Mohri H, Lahoti S, Saito O, Mahalingam A, Gunatilleke N, Van Thang Hoang I, Hitinayake G, Takeuchi K, Herath S (2013) Assessment of ecosystem services in homegarden systems in Indonesia, Sri Lanka, and Vietnam. Ecosyst Serv 5: 124-136.

[55] Weerahewa J, Pushpakumara G, Silva P, Daulagala C, Punyawardena R, Premalal S, Miah G, Roy J et al (2012) Are homegarden ecosystems resilient to climate change? An analysis of the adaptation strategies of homegardeners in Sri Lanka. APN Sci Bull 2: 22-27.

[56] Kumar BM, Nair PKR (2004). The enigma of tropical home gardens. Agrofor Syst 61: 135-152.

[57] Pushpakumara DKNG, Marambe B, Silva GLLP, Weerahewa J, Punyawardena BVR (2012) A review of research on homegarden in Sri Lanka. The status, importance and future perspective. Trop Agric 160: 55-125.

[58] Schroth G, Mota MSS, Hills T, Soto-Pinto L, Wijayanto I, Arief CW, Zepeda Y (2011) Linking carbon, biodiversity and livelihoods near forest margins: the role of agroforestry. In: Kumar BM, Nair PKR (eds) Carbon sequestration potential of agroforestry systems: opportunities and challenges. Springer, Dordrecht, pp 179-200.

[59] Yachi S, Loreau M (1999). Biodiversity and ecosystem productivity in a fluctuating environment: the insurance hypothesis. Ecology 96: 1463-1468.

[60] Brookfield H, Stocking M, Brookfield M (2002) Guidelines on agro-diversity assessment. In: Brookfield $\mathrm{H}$, Padoch $\mathrm{C}$, Parsons $\mathrm{H}$, Stocking $\mathrm{M}$ (eds) Cultivating biodiversity: understanding, analyzing and using agricultural diversity. ITDG Publishing, London, pp 41-56.

[61] Henry M, Tittonell P, Manlay RJ, Bernoux M, Albrecht A, Vanlauwe B (2009) Biodiversity, carbon stocks and sequestration potential in aboveground biomass in smallholder farming systems of western Kenya. Agric Ecosyst Environ 129 (1): 238-252.

[62] FAO (2010 a). Homestead gardens in Bangladesh. Technology for agriculture. Proven technologies for small holders. http://www.fao.org/teca/content/homestead-gardensbangladesh. Accessed 24 April http://www.scirp.org/journal/ojf, http://dx.doi.org/10.4236/ojf.2014.45049).

[63] Haq R, Kumar T, Ghosh P. 2009. Soil-less agriculture gains ground. LEISA Magazine 25 (1): 35.

[64] Gebauer J, 2005, Plant Species Diversity of Home Gardens in El Obeid, Central Sudan; Journal of Agriculture and Rural Development in the Tropics and Subtropics Volume 106, No. 2, 2005, pages 97-103.

[65] Ewuketu L, 2014. Agro-ecosystem and socio-economic role of home garden agroforestry in Jabithenan District, NorthWestern Ethiopia: implication for climate change adaptation, Debremarkos University, Debremarkos, Ethiopia. 
[66] Wezel and Alexander, 2003; Plant species diversity of homegarden in humid and semiarid Cuba and its importance for self-sufficiency of households, Conference on International Agricultural Research for Development, Gottingen.

[67] Feleke W, Zemede Asfaw, Sebsebe Demissew, and Bernard
Roussel, 2016; Home gardens (Aal-oos-gad) of the Basket People of Southwestern Ethiopia: Sustainable agroecosystems characterizing a traditional landscape.

[68] ICRAF (2011). A submission to the UNFCCC Subsidiary Body for Scientific and Technological Advice on issues related to agriculture. 